\title{
Vijay Naidu
}

\section{Changing Gears on the}

Millennium

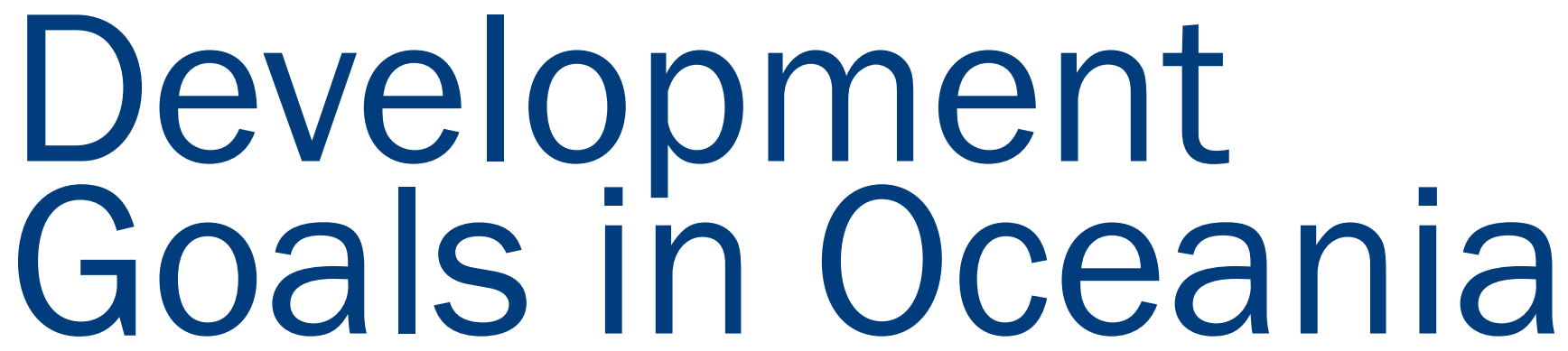

\section{Introduction}

Even before the onset of the global economic recession in late 2008, Sub-Saharan Africa and Oceania were deemed to be seriously lagging behind in achieving the Millennium Development Goals (MDGs) and there was concern that many of the goals will not be met by 2015. While the challenges in Sub-Saharan Africa are seen to be of a much higher magnitude than those in Oceania, for the latter to achieve all the goals in the next seven years requires significant new policy initiatives and their more effective implementation, as well as renewed partnerships which will drive sustainable actions towards the MDGs.

In a 2008 monograph (on which this article is based) entitled A Slice of Paradise? The Millennium Development Goals in the Pacific: progress, pitfalls and potential solutions, Terence Wood and I provided a comprehensive assessment of the MDGs themselves and the progress towards achieving them in this

Vijay Naidu is Professor and Director of the Development Studies Programme and Pacific Institute of Advanced Studies in Development and Governance (PIAS-DG) at the University of the South Pacific. Throughout his career he has published extensively in the area of development.

region, as well as solutions to overcoming the obstacles. This article gives an overview of progress, or lack thereof, on the MDGs, identifies the obstacles and suggests changing gear as we seek greater traction to achieve the goals.

\section{Oceania's progress on MDGs}

In the 1990s Oceania was much better placed compared to many other regions of the global south in terms of human development indicators. Per capita incomes and education and health standards, as well as life expectancies, were generally higher. However, since then there has been slippage and lack of improvement in social development in many Pacific Island countries, and achieving all the MDGs with current policies by 2015 is most unlikely.

First, with respect to MDG 1 (the eradication of poverty and hunger), the percentage of people living below the respective national poverty lines in Oceania ranges from 


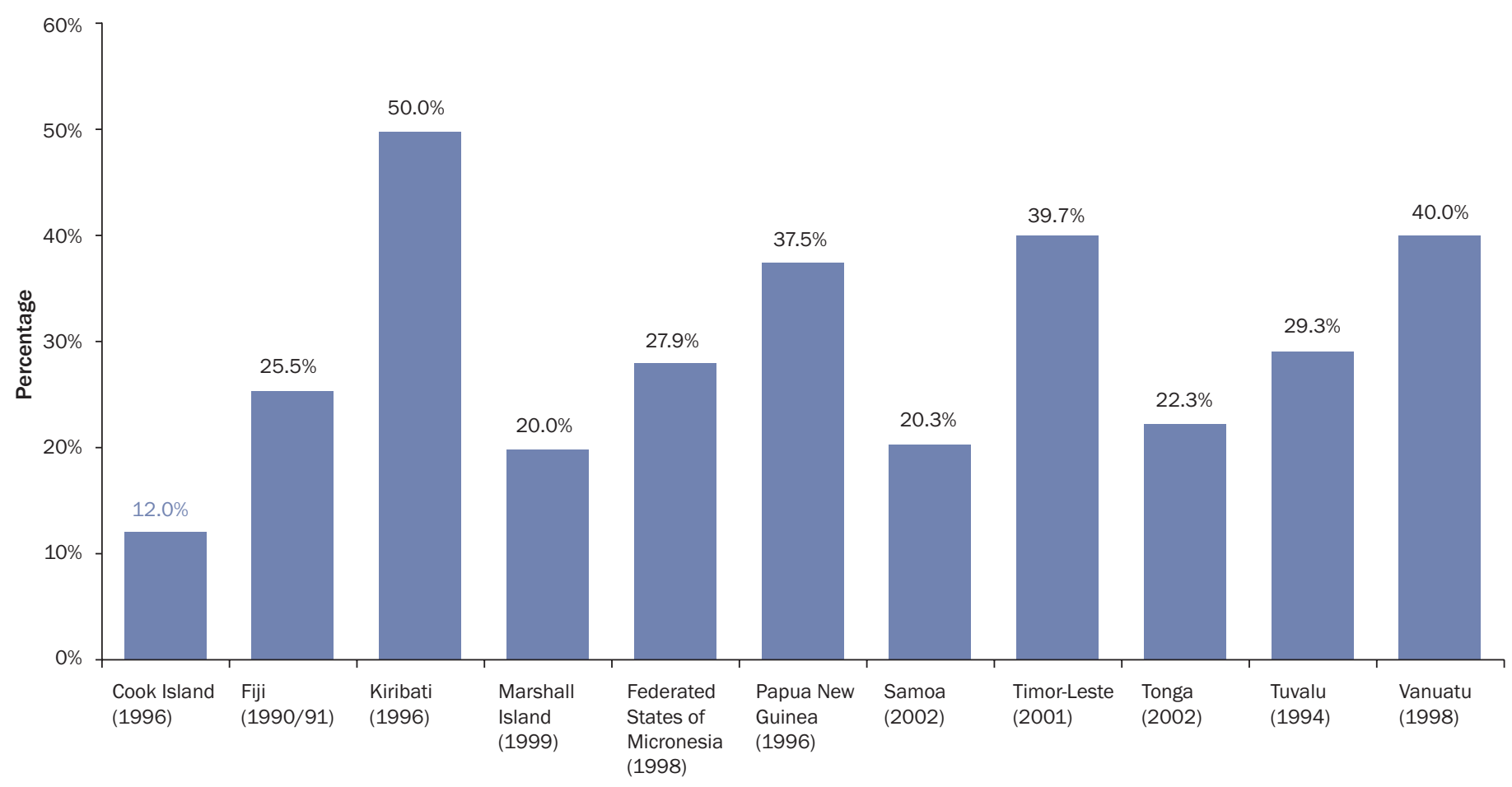

Country (number in brackets denotes the year the data was collected)

Source: Abbott and Pollard (2004, P.28)

around $12 \%$ in the Cook Islands to $50 \%$ in Kiribati, with that in the larger Pacific Island countries of Fiji, Papua New Guinea, Solomon Islands and Vanuatu ranging between $30 \%$ and 40\% (Asian Development Bank, 2004). Even though the 'poverty denial syndrome' has been challenged in most Pacific Island countries (see Figure 1), its residue of a downplaying of the extent and intensity of poverty remains. Without a wider appreciation of growing inequality, poverty, social exclusion and the erosion of traditional safety nets, effective responses to reduce poverty will not occur. Indeed, from a situation where the desperately poor are a minority there can be significant increases in their number. Already in certain slums of Port Moresby it is often the case that the stark choice facing young men and women is engaging in either crime or commercial sex.

Second, trends in the provision of 'education for all' are mixed, and in any case there is a need to go beyond a 'bums on seats' approach with respect to access to education at all levels (MDG 2). It is not a question only of the proportion of school-aged children attending classes, but of the quality of education being provided. There has been a positive trend in the proportion of children attending schools, but in the larger Pacific Island countries there are concerns both with attendance and the quality of education. Countries such as Nauru and the Marshall Islands have experienced deteriorating educational outcomes. Post-1987 coup Fiji has also witnessed a decline in both enrolments and quality of educational services. Table 1 provides statistics for selected Pacific countries. In Fiji, the large-scale emigration of wellqualified and experienced teachers has been a significant factor in this lowering of standards.
Table 1: Education statistics for selected Pacific Island countries

\begin{tabular}{|c|c|c|c|c|}
\hline \multirow{2}{*}{$\begin{array}{l}\text { Indicators } \\
\text { Year }\end{array}$} & \multicolumn{2}{|c|}{$\begin{array}{r}\text { Net enrolment ratio in } \\
\text { primary education - } \\
\text { percentage }\end{array}$} & \multicolumn{2}{|c|}{$\begin{array}{r}\text { Proportion of pupils } \\
\text { starting Grade } 1 \\
\text { who reach Grade } 5 \text { - } \\
\text { percentage }\end{array}$} \\
\hline & 1990 & 2000 & 1990 & 2000 \\
\hline Cook Islands & & $\begin{array}{r}92.3 \\
(2001)\end{array}$ & $\begin{array}{r}100 \\
(1986)\end{array}$ & $\begin{array}{r}98.2 \\
(1996)\end{array}$ \\
\hline Fiji & 92 (1986) & 94.7 & $\begin{array}{r}91.4 \\
(1996)\end{array}$ & $\begin{array}{r}88.4 \\
(2002)\end{array}$ \\
\hline $\begin{array}{l}\text { Federated States } \\
\text { of Micronesia }\end{array}$ & $\begin{array}{r}93.7 \\
(1994)\end{array}$ & 92.3 & & 66.9 \\
\hline Kiribati & 76.2 & 93.5 & 98 & \\
\hline Marshall Islands & $\begin{array}{r}89.7 \\
(1988)\end{array}$ & $\begin{array}{r}84.1 \\
(1999)\end{array}$ & 88 (1988) & $\begin{array}{r}86.1 \\
(1999)\end{array}$ \\
\hline Nauru & $\begin{array}{r}75.1 \\
(1992)\end{array}$ & $\begin{array}{r}60.3 \\
(2002)\end{array}$ & & $\begin{array}{r}92 \\
(2002)\end{array}$ \\
\hline Niue & & $\begin{array}{r}90.2 \\
(2001)\end{array}$ & & $\begin{array}{r}90.5 \\
(2001)\end{array}$ \\
\hline Palau & 81.8 & 76.2 & & \\
\hline PNG & 66.3 & 77.4 & 58.1 & 56.8 \\
\hline Samoa & 82 (1991) & 87 (2001) & & 84 (2001) \\
\hline Solomon Islands & 39 (1986) & 56 (1999) & 85 (1991) & \\
\hline \multicolumn{5}{|l|}{ Tokelau } \\
\hline Tonga & $\begin{array}{r}91.6 \\
(1986)\end{array}$ & $\begin{array}{r}89.4 \\
(1996)\end{array}$ & 84 & \\
\hline Tuvalu & $\begin{array}{r}98.2 \\
(1991)\end{array}$ & $\begin{array}{r}99.6 \\
(2002)\end{array}$ & $\begin{array}{r}95.8 \\
(1993)\end{array}$ & \\
\hline Vanuatu & $\begin{array}{r}74.5 \\
(1989)\end{array}$ & $\begin{array}{r}78.2 \\
(1999)\end{array}$ & $\begin{array}{r}90.2 \\
(1991)\end{array}$ & 91.2 \\
\hline
\end{tabular}

Source: Secretariat of the Pacific Community (2004, p.38) 
Given the demographic trends in Micronesia and Melanesia, there is a need for more schools being established as well as for more trained teachers.

Third, with regard to MDG 3, which addresses gender, broadly speaking there are improvements in gender-related indicators with respect to education and non-agricultural employment (though this can be quite misleading), but not in relation to women's representation on decision-making bodies, particularly national parliaments. Incidents of domestic violence and gender-related crimes appear to be increasing in many Pacific Island countries.

As recently as 1987 there were only six reported cases of HIV infection in Papua New Guinea, yet by the end of 2003 an estimated $0.6 \%$ and possibly as many as $1 \%$ of Papua New Guinea's population were thought to be HIV positive

Fourth, for almost all Pacific Island countries the trends in infant and child mortality are towards lower mortality rates (Secretariat of the Pacific Community, 2004). But child and maternal mortality (MDGs 4 and 5) remain major issues in a number of countries, both big and small. Along with Papua New Guinea, there are three countries which provide particular cause for concern with respect to child and infant health: in Nauru and Timor Leste infant mortality rates have increased in recent years, while in Fiji infant and child mortality rates have seen little or no improvement over the last 10 years (ibid).

Fifth, for most of those Pacific Island countries for which time series of maternal mortality rates are available the trend is broadly positive - i.e. maternal mortality is reducing. However, there are some causes for concern. Papua New Guinea and East Timor have very high maternal mortality rates that are diminishing only slowly. Likewise, Solomon Islands has a very high maternal mortality rate which increased during the years in which the islands were affected by conflict (Solomon Islands Government, 2005).

Sixth, the state of health in Oceania varies widely, and the current focus of MDG 6 on malaria, HIV/AIDS and tuberculosis does not provide an accurate picture of health in the region. Malaria debilitates and kills people in Papua New Guinea, Solomon Islands and Vanuatu but is not present in other Pacific Island countries. The presence of TB is also limited but likely to grow.

Fortunately, with the notable exception of Papua New Guinea most of the Pacific has thus far been spared the worst of the HIV epidemic. However, it seems highly likely that, unless major action is taken, the incidence of HIV will increase dramatically across the Pacific in the near future (AIDS New Zealand, 2005; UNAIDS, 2004). There are a variety of reasons for this, including:

- current statistics for HIV incidence in the Pacific almost certainly under-represent the prevalence of the disease, as most countries do not currently have adequate HIV testing programmes, and in addition the stigma associated with HIV discourages people from being tested for the illness (AIDS New Zealand, 2005);

- there are high rates of teenage pregnancies and sexually transmitted illnesses (STIs), which are indicative of unsafe sex practices, and existing STIs are thought to facilitate the transmission of HIV (AIDS New Zealand, 2005; UNAIDS, 2004);

- religious beliefs and other cultural practices make the discussion of sexual matters taboo and are barriers to safe sex and other illness awareness programmes that will be required to stop HIV from spreading (AIDS New Zealand, 2005);

- patriarchal systems and increased population mobility, including labour mobility (for example, seafarers in Kiribati and Tuvalu and security personnel in Fiji);

- tourism.

The case of Papua New Guinea provides a sobering example for the rest of the Pacific of just how rapidly HIV rates can rise if no action is taken. As recently as 1987 there were only six reported cases of HIV infection in Papua New Guinea, yet by the end of 2003 an estimated $0.6 \%$ and possibly as many as $1 \%$ of Papua New Guinea's population were thought to be HIV positive ${ }^{1}$ (Centre for International Economics 2002, p 81; UNAIDS, 2004, p 1). And in Lae - Papua New Guinea's second largest town $-2.5 \%$ of all pregnant women (who are routinely tested for the disease) were found to be HIV positive in 2004 (UNAIDS, 2004, p.1). It seems highly likely that, unless a concerted effort is made to stop the rise of HIV in the Pacific, the disease may well impede the region's progress not only on MDG 6 but on many of the other Millennium Development Goals as well. ${ }^{2}$

It is also likely that the incidence of non-communicable diseases such as diabetes and cardiovascular disease will increase in the Pacific in the near future, because the rates of non-communicable disease risk factors - such as obesity and smoking - are some of the highest in the world (Secretariat of the Pacific Community, 2004). These non-communicable diseases are already imposing a notable burden on many Pacific Island countries' health systems.

Seventh, the targets and indicators of MDG 7, which pertains to the environment, can be split into two broad categories: those that relate directly to the environment, and those that refer to environmental factors affecting human needs. The former include forest cover, land area protected to maintain bio-diversity, energy efficiency and emission of greenhouse and ozone-depleting gasses. The latter comprise safe drinking water, sanitation and land tenure security. The 
last two of these indicators are seen to especially impinge on the lives of urban slum dwellers.

Data on the four environmental indicators are not readily available, but forest cover in most smaller island states has been sparse and largely destroyed. In Fiji, Papua New Guinea, Solomon Islands and Vanuatu there has been a considerable increase in logging that is often illegal and unsustainable. The loss of tropical rainforests and the spread of human settlements, agriculture and infrastructural development have had adverse effects on bio-diversity. Similarly, many coastal zone areas are under stress. Sophisticated fishing technologies are also jeopardising tuna and other fisheries. Without data, it is difficult to say anything really meaningful with respect to energy efficiency and greenhouse gas emissions except that very belatedly there appears to be more serious consideration being given to renewable energy use, and that Pacific Island countries are not responsible for large greenhouse gas emissions.

Safe drinking water is in short supply in the larger island states and in the atoll states, for rather different reasons. In the former, water is plentiful in most parts but there is either an absence of reservoirs and piped water or existing public water systems have been allowed to deteriorate. In the latter, arid conditions and the intrusion of salt water into fresh water lenses affect the quality of water. Sanitation is of much concern in Pacific Island countries, and this is especially so in the numerous informal settlements that are springing up from South Tarawa to Port Moresby.

\section{Obstacles to meeting the Millennium Development Goals in the Pacific}

Impediments to achieving the MDGs by 2015 derive from external and internal factors. Exogenous forces include the push towards free trade and globalisation, the loss of preferential access to international markets and the current world economic downturn. Internal factors include the absence of reliable data on MDG indicators, which is an extension of the widely prevalent lack of capacity in state institutions; geographical challenges; conflict; weak governance; and the failure to promote robust partnership with civil society and donor agencies.

\section{MDGs' countervailing contextual environment}

\section{Economic globalisation and neo-liberalism}

Globalisation and neo-liberal economic policies being pushed by powerful agencies and incorporated in the economic integration pillar of the Pacific Plan undermine the capacity of communities to sustain livelihoods and the ability of island states to generate the revenues necessary to support MDGrelated activities. Compliance with World Trade Organisation rules and with regional and international trade agreements has serious implications with respect to employment, pro-poor growth and the provision of social services

The Pacific Island Countries Trade Agreement (PICTA) and the Pacific Agreement on Closer Economic Cooperation (PACER), as well as the Economic Partnership Agreements (EPAs) currently being negotiated by the European Union, are all directed at 'freeing up' and economic integration. The PICTA agreement relates to trade between the Pacific Island countries, while the PACER agreement pertains to trade between the Pacific Island countries and Australia and New Zealand (Narsey, 2004). Both agreements have trade liberalisation at their centre. European Union EPAs are being negotiated with the expiry of the Lomé and Cotonou trade agreements. With the intense pressure of the European Union on Pacific ACP (African, Caribbean and Pacific) countries (signatories to the Lomé and Cotonou agreements) to negotiate and accede to EPAs on a regional basis, Pacific ACP countries' efforts at regional solidarity have collapsed. Fiji and Papua New Guinea have signed an interim agreement to
Another concern associated with the free trade agenda for the Pacific is the impact of the agenda on those workers in the Pacific Island countries who are currently employed in economic activities that may, in the event of trade liberalisation, be adversely affected. meet the EU deadline, thereby weakening the position of the Pacific ACP group. It is likely that as the EU's EPA imposition is finalised, this will trigger Australia and New Zealand's push for PACER to be brought forward.

Subscribing to the free trade ideology in the Pacific is likely to impede attaining the MDGs in the region, as there will be a loss of government revenues associated with the reduction or removal of trade tariffs. At present, almost all Pacific Island countries obtain a significant proportion of their government revenue from the collection of tariffs and import duties, and in some tariff revenues comprise more than $60 \%$ of total government revenue (Coates and Lennon, 2005; Scollay, 2001). The reduction of tariffs as a source of government revenue will have one of two consequences: reduced government services, or taxes having to be raised from alternative sources. In the case of reduced government services there is a clear risk that these reductions will take place in either health or education, in which case they may well lead to deterioration in MDG indicators. In the case of tax increases - particularly if the increases take the form of a value added tax (VAT), as was imposed in Vanuatu and is being discussed in the Marshall Islands - the brunt of these increases may well fall on the islands' poor (Coates and Lennon, 2005; Firth, 2005; Gay and Joy, n.d.). 
Another concern associated with the free trade agenda for the Pacific is the impact of the agenda on those workers in the Pacific Island countries who are currently employed in economic activities that may, in the event of trade liberalisation, be adversely affected (Narsey, 2004). Conventional economic theory predicts that, after tariffs and other protections are removed, even if some sectors are destroyed the economy will simply restructure itself in a more efficient manner and those workers who were made unemployed will be re-employed in new sectors that emerge. However, it is highly debatable that such economic theory is applicable in the Pacific Island case, where the scope for new industries to form is limited by the geographical and cultural constraints of the region (Coates and Lennon, 2005; Firth, 2005). As such, the negative impacts of trade liberalisationrelated job losses may be long lived.

Both the Lomé and Cotonou agreements provided Pacific Island countries with preferential access to European part of family earnings' (ibid.). From its early 2000 peak of exporting more than F\$300 million and employing between 18,000 and 20,000 workers, Fiji's garment industry is now near collapse, with the number of people employed reduced by between two-thirds and three-quarters (Storey, 2006).

Vanuatu also implemented neo-liberal economic policies, in this case at the behest of the Asian Development Bank. Lennon (2005, p.8) describes the results of these policies as follows:

The CRP [the Comprehensive Reform Programme the name for the neo-liberal policies] has now been in operation for eight years. There is general consensus in Vanuatu that the CRP has largely failed in its objectives. Warning signs were apparent shortly after the CRP was implemented: GDP immediately began to shrink, exports plummeted and foreign investment declined ... Government revenue declined sharply (and has only just recovered), in part due to the loss of tariff revenue, which was not fully replaced by VAT. Another major source of revenue loss has been the sell-off of profitable assets ... Reforms under the CRP have failed to provide tangible economic benefits for Vanuatu's population. In urban areas, unemployment rates, which were very low, have risen significantly.

Unfortunately, neither the Asian Development Bank nor the government of Vanuatu made any significant attempt to markets for some agricultural commodities, as well as special pricing for sugar (Firth, 2005; Oxfam, 2005). In Fiji, the most significantly affected country, the Lomé and Cotonou agreements enabled the sugar industry to provide livelihoods for thousands of farmers (Firth, 2005). However, the Cotonou agreement has recently been deemed WTO-incompatible and the European Union is significantly reducing preferential access in the EPAs it is negotiating in Cotonou's wake. Firth (2005, p.5) explains the significance of this:

Whatever the final outcome for sugar, it is certain to be less favourable than existing arrangements and to lead to a drastic decline of the Fiji sugar industry, which is estimated to provide employment for more than 40,000 people in a country of only 820,000 ... And while the mantra of the globalizers is that Fiji should restructure its economy accordingly, the prospects for successful restructuring are far from obvious.

Along with the Lomé agreement, Fiji is also being affected by the end of another WTO-incompatible trade regime: the Multi Fibre Arrangement, which expired in 2005. The expiry of the Multi Fibre agreement had an impact on those Fijian garment producers who exported to the United States, and, according to Firth, 'delivered a blow to an industry that earns more for Fiji than sugar and employs about 14,000 people, many of them women whose cash income is a major record trends in the incidence of poverty over the period of the reforms, yet it seems highly likely, given the facts above, that poverty increased in Vanuatu during this time.

Meanwhile, in the Cook Islands, as part of broader neo-liberal economic reforms which entailed downsizing the public service by two-thirds, the education budget was almost halved in the mid-1990s, while the budget for housing and community services was reduced from $\$ 9$ million to $\$ 1$ million over the same period (ACFOA, 2002, p.11). And in Tonga, reforms led to increased prices for services such as electricity (ACFOA, 2002).

These Pacific Island experiences, combined with considerable evidence accumulating from other parts of the world which shows neo-liberal policies either generating increased rates of poverty or failing to reduce poverty in any meaningful sense (Barton, 2005; Focus on the Global South, 2003; Hardstaff, 2005; Rodrik, 2004; Stiglitz, 2002), lead us to believe that neo-liberal economic policies have the potential to become a significant obstacle to attaining the MDGs in the Pacific.

\section{Intra-regional and national obstacles to achieving the MDGs Problems of geography}

Pacific Island countries are both diverse geograhically and dispersed. In some, such as Tuvalu and Tokelau, which have very little land and few resources, the geographical constraints 
to development are obvious. Even Papua New Guinea, the Pacific's largest country, has its own unique geographical constraints, including the inaccessibility of its rugged interior regions which hinders trade and limits political control, and the effect of malaria on its population. The 'curse of resource abundance' is a danger larger countries face.

\section{Problems of institutions and governance}

Pacific states have numerous issues with respect to their capacity to meet contemporary challenges of governance. These range from law and order, revenue generation and facilitation of sustainable development to the provision of services. Another is that any meaningful discussion of MDGs is affected by the lack of goal-specific indicator data in virtually all countries. No country has collected MDG indicator-specific data and the information available is generally open to question. There is also the issue of the high probability of inbuilt bias because of the monopoly held by data-gathering institutions. There is an absence of accurate time series data, so that trends can not be identified. Moreover, the Oceania-wide aggregation of data misrepresents country-level progress towards the goals. Data quality is a fundamental problem that must be addressed if we are to meaningfully discuss progress on MDGs.

The increased focus on governance and institutions in the Pacific is not only a reflection of international trends, but has also come about because of the numerous scandals that have rocked the region in recent years. These scandals include the F\$220 million National Bank of Fiji fiasco; the sale of passports by officials in Tonga, Samoa and Kiribati; multimillion-dollar open government guarantees to con artists by political leaders in the Cook Islands and Vanuatu; the loss of millions of dollars by Nauru through mismanagement which extended to funding a play in London by one of its dubious foreign advisers; and the disappearance of US $\$ 20$ million entrusted to the king of Tonga's official American court-jester-cum investment adviser (Naidu, 2002, p.3).

With respect to corruption alone, the Asian Development Bank estimates that one third of all public investment is squandered on corruption in the Asia and Pacific region (Asian Development Bank, 2004, p.8). And the impact of poor governance is not limited just to corruption either: poor governance and weak institutions have led to a multitude of problems in the region above and beyond financial scandals. These problems include: limited democracies in some countries (such as Tonga) and unstable democracies in others (such as Fiji and Solomon Islands); inefficient provision of public services and infrastructure; and human rights abuses and police brutality (as has been seen recently in Fiji and Papua New Guinea) (Naidu, 2002; Human Rights Watch, 2005; Gibbs, 2007).

Many of the issues of governance and institutions in the Pacific are, in part at least, products of colonial inheritance, and even in the current age forces leading to poor governance and institutional weakness in the developing world often flow from developed-world business interests (Birdsall et al., 2005; and see Kahn, 2000 for an alleged example of this in the Pacific).

Too often 'good governance' and 'improved institutions' are simply seen as reduced corruption and efficient economic management. Yet such an approach misses the fact that, for genuine human development to take place, the improvement of governance and institutions needs to come about as part of the deepening and reinforcing of the democratic process. Without this there is no guarantee that the benefits of economic growth will ever be distributed equitably throughout a society (Bendana, 2004). Furthermore, experiences in other parts of the developed and developing world show that a strong civil society coupled with a transparent democratic process is an effective way of ensuring good governance in the long term (Putnam et al., 1994; Wood, 2004).

\section{Conflict}

Conflict is (or has been) a serious issue in several Pacific countries and is (or has been) a minor issue in several others. The four Pacific Island countries most seriously affected by conflict in recent years have been Fiji, Papua New Guinea, Solomon Islands and Tonga. The social and economic price of conflict has affected their ability to meet the Millennium Development Goals. And while not all Pacific Island countries are affected by conflict, few should be considered completely immune to the risk of it arising. It is, therefore, maintained that the issue of conflict in the Pacific needs to be taken seriously if the MDGs are to be met.

\section{Partnership I: international (MDG 8)}

If the MDGs are to be met, key public services such as education and health need to be adequately funded (Vandemoortele, 2002). Similarly, action needs to be taken to arrest the spread of HIV and non-communicable diseases, and conflict resolution. All of which needs to be paid for. At present, the budgets of most Pacific Island countries are simply not up to funding these urgent tasks. As such, unless overseas development assistance increases, its inadequate levels will remain a hurdle to achieving the MDGs.

Quantity is not the only issue associated with overseas development assistance and the MDGs in the Pacific; there is also that of quality. By 'poor quality assistance' we refer to development assistance that is either given to inappropriate projects, tied to the purchase of goods from the donor country, or spent primarily on paying for the services of developed- 
country contractors and consultants. The contrast between overseas development assistance given by New Zealand and that given by Australia illustrates both what poorly given assistance looks like and also the potential for improvements to be realised. Greenhill and Watt (2005, p.25) estimate that $33 \%$ of Australia's overseas development assistance is tied to the purchase of Australian goods; while with respect to the quantity of aid paid to developed-world contractors and consultants, Aid/Watch (2005, p.1) notes that well over half of Australian aid ends up being paid to Australian companies. Aid/Watch also provides an example of an AusAID funded project in Papua New Guinea where overseas contractors were being paid over AUD \$1,000 a day for their work while local workers were receiving little over $\$ 1$ per day (Aid/ Watch, 2005, p.1). This contrasts with overseas development assistance given by New Zealand, which, while not perfect, has improved considerably in recent years. Indeed, NZAID, since it became a separate department of the Ministry of Foreign of the world's top government aid agencies, following best practice in a variety of areas (DAC, 2005). Unfortunately, New Zealand tends to be the exception to the rule when it comes to Affairs and Trade, has gained for itself a reputation as one

it is also clear that there is much hard work to be done in the region.

\section{Improved collection of statistics}

Better statistics will enable trends in the relevant MDG indicators to be identified, and ought to enable the targeting of overseas development assistance and government programmes to areas of concern. In light of this, recent work on assessing progress towards the MDGs undertaken by the Asian Development Bank and the Secretariat of the Pacific Community in these areas should be seen as a step in the right direction. However, there is still much work to be done and government statistics agencies will also need continued strengthening. In addition to this, we are concerned that almost all of the current collection of relevant statistics in the Pacific is undertaken either by governments or by multilateral organisations: organisations which may have a vested interest in 'showing' good performance in relation to the MDGs. Biases may occur. For this reason there needs to be some role for civil society organisations in monitoring the collection and reporting of statistics.

\section{Increased and better overseas development assistance}

Because of the role that the quality of overseas development assistance has in fostering better developmental outcomes, including achievement of the MDGs, it is important that donors in the Pacific concentrate on improving the manner in which development assistance is given in

the major donor countries in the Pacific. Also, as a relatively small economy the absolute levels of development assistance from New Zealand are less than those of larger countries such as Australia. For these reasons, until other donors follow New Zealand's lead overseas development assistance quality will accompany overseas development assistance quantity as being a hurdle to meeting the MDGs.

The final hurdle for the MDGs in the Pacific is the attitudes of developed-world nations and, most importantly in the Pacific, Australia and New Zealand - to the process of development. Clearly, the needs of Pacific Island countries are diverse and distinct from the needs of Australia and New Zealand. And until this is recognised by the governments of these two countries their actions will remain an obstacle to attaining the MDGs. It is worth noting that, of the two countries, only New Zealand has taken any action (and even this is relatively minor) on seasonal labour migration as suggested in the Pacific Plan as a quid pro quo in the trade liberalisation process. Yet seasonal labour migration is one aspect of globalisation that has the potential to at least aid human development in the Pacific (Maclellan and Mares, 2005).

\section{Changing gears and overcoming the obstacles to MDGs}

Some Pacific Island countries already exceed almost all of the MDGs, while most are on track to achieve some of them. Yet the region.

Firstly, overseas development assistance needs to stop being tied to the purchase of goods in donor countries. With respect to the ending of 'tied' aid, New Zealand has become, through the untying of all aid, an example of best practice for the region. Unfortunately, Australia still lags in this area.

Overseas development assistance also needs to be given free of conditionalities that compel governments to adhere all conditionalities associated with aid are bad; indeed, conditionalities which prohibit aid being spent on military items or lining the pockets of officials are a desirable component of sensible overseas development assistance provision. However, conditionalities that require countries to excessively privatise their economies or open up to international trade should not be imposed. In addition to this, a significant portion of overseas development assistance should continue to be targeted to poverty reduction, along with health and education. Furthermore, efforts should be made to ensure that no more overseas development assistance is spent on technical advice and foreign consultants than is absolutely necessary.

Finally, overseas development assistance needs to be given in a manner that does not foster corruption. There is some evidence showing that, historically, overseas development to inappropriate economic policies. This is not to say that 
assistance has led to corruption in developing countries (Greenhill and Watt, 2005). Yet it need not do this. Too often in the past when overseas development assistance was given it was given for geo-strategic reasons rather than with the aim of promoting development. Often, because of these geo-strategic motives, a blind eye was then turned to resulting corruption. In addition to this, overseas development assistance can be used, if given wisely and targeted in the right areas, to strengthen institutions. Careful investment in institution strengthening offers the potential for overseas development assistance to actually reduce corruption.

\section{Economic reform, trade policy and trade negotiations}

As noted previously, the free-trade agenda for the Pacific has been part of a broader neo-liberal project in the region. This project has seen Pacific Island countries advised to cut government spending, privatise some state-owned industries and implement other 'market friendly' economic reforms. In many cases the consequences of this for human development have been negative. Of particular concern has been the cutting (or freezing) of state expenditures in key areas such as health and education. As Vandemoortele (2002) notes, the experiences of countries that have coupled economic growth with significant human development show that sustained social spending does not in any way hinder economic growth and is, at the same time, integral to human development. While Pacific Island countries need to avoid accruing large budget deficits, they still need to maintain adequate social spending programmes. If government tax revenue is not sufficient for this to occur, then the shortfall ought to be made up from overseas development assistance.

Along with maintaining social spending, a more considered approach to the privatisation of government enterprises needs to be undertaken in Pacific Island countries. This approach ought to recognise that while in some cases privatisation may be justified, it is not inevitably the right course of action. As a variety of international experiences show, state owned enterprises can be run efficiently and even profitably and so need not inevitably lead to increased government spending. Moreover, when privatisation leads to natural monopoly it is likely that price setting will take place and consumers will suffer. Furthermore, in many Pacific Island countries the state is a major employer, meaning that any sale of state owned enterprises or reduction in government staff needs to be assessed not only with respect to economic management, but also with respect to the social and multiplier costs associated with staff losing their jobs.

Australia and New Zealand can contribute immensely to human development and MDGs in Pacific Island countries by supporting seasonal labour schemes. Such schemes should be accompanied by skills training to enhance the capacity of the workers to contribute to their communities.

\section{Pre-empting conflict and promoting effective conflict resolution}

Proactively, mediation, reconciliation and peace-building institutions and processes should be established to address emerging conflict situations. Conflicts seriously jeopardise progress towards MDGs. Outside intervention ought to be considered as part of attempts to resolve them. This should be undertaken under the auspices of the Pacific Islands Forum and through processes that will contribute to longerterm commitment to peace and stability.

\section{Partnerships II: strengthened civil society and deepened democracy}

The UN Millennium Project (2005, p.32) explains the importance of the role of civil society in democratic governance in the following way:

Strong civil society engagement and participation are crucial to effective governance because they bring important actors to the fore, ensure the relevance of public investments, lead to discussions that best address the people's needs as they perceive them and serve as watchdogs for the development and implementation of government policies.

\section{Globalising means civil society organisations acting in collaboration with other Pacific (and international) civil society groups, making use of a combined voice that is stronger than that of individual organisations working on their own.}


If civil society is to play a significant role in human development in the Pacific (and in enabling MDGs to be met) it needs outside assistance. Such assistance may involve (as is currently given) overseas development assistance to fund specific programmes; it should also involve funding that directly aids civil society organisations in capacity building and in overcoming obstacles that they face. Finally, assistance should be provided to Pacific civil society organisations to enable them to both globalise and localise. Globalising means civil society organisations acting in collaboration with other Pacific (and international) civil society groups, making use of a combined voice that is stronger than that of individual organisations working on their own. Localising means space being provided to allow domestic civil society organisations to develop in a manner that is most appropriate to the local context within which they work. If all this is done then civil society has the potential to be a powerful reforming force in Pacific Island countries.

\section{Conclusion}

Oceania's lag in meeting Millennium Development Goals should serve as a wake-up call that the business-as-usual approach is not working. And, if it is continued, the outlook for the region is not likely to be positive.
As a region the Pacific is far from a 'basket case', and, as has been argued in this article, the problems that confront it can be overcome. For this to occur, however, business-as-usual needs to be replaced by a new approach to the development of the region. Such an approach will, by necessity, require that several things occur. Firstly, the neo-liberal orthodoxy that has been imposed on the region needs to be reconsidered and adapted so that human development is brought to the fore. Secondly, economic policies need to be designed taking into account the region's unique geography and culture. Thirdly, more overseas development assistance needs to be given to the region and its delivery needs to be considerably improved. Fourthly, when it comes to trade, and trade negotiations, the two regional powers need to stop acting with only their selfinterest at heart. Fifthly, concerted efforts need to be made to prevent conflict in the region. And finally, institutional reform needs to take place within Pacific Island countries, ideally in a manner that couples reform with the deepening of democracy. Promoting civil society organisations is a sine qua non of this process.

\footnotetext{
1 In absolute numbers it is thought that as many as 28,000 people were HIV positive in Papua New Guinea by the end of 2004 (UNAIDS 2004c, p1).

2 For a discussion of the potential economic impacts of HIV on Papua New Guinea, see Centre for International Economics (2002).
}

\section{References}

Abbott, D. and S. Pollard (2004) Hardship and Poverty in the Pacific, Manila: Asian Development Bank

ACFOA (2002) Inquiry into Australia's Relationship with Papua New Guinea and Other Pacific Island Countries: submission to the Senate Foreign Affairs, Defence and Trade References Committee, Canberra: Australian Council for Overseas Aid, AIDS New Zealand (2005) 'Update on HIV/ AIDS in the Pacific Region', AIDS New Zealand, 56, August

Aid/Watch (2005) Boomerang Aid: not good enough minister!, Australia: Aid/Watch

Asian Development Bank (2004) 'The Millennium Development Goals: will Asia and the Pacific achieve them?', $A D B$ Review, 36 (3), June

Barton, C. (2005), 'Women's movements and gender perspectives on the Millennium Development Goals', in C. Barton, M. Kohr, S. Narain and V. Tauli-Corpuz (eds), Civil Society Perspectives on the Millennium Development Goals, New York: UNDP

Bendana, A. (2004) Good Governance and the MDGs: contradictory or complementary?, available at http://www.focusweb.org/ main/html/Article518.html, accessed 21 September 2005
Birdsall, N., D. Rodrik and A. Subramanian (2005) 'How to help poor countries', Foreign Affairs, 84 (4), July/August

Centre for International Economics (2002) Potential Economic Impacts of an HIV/AIDS Epidemic in Papua New Guinea, Canberra: AusAID

Coates, B. and S. Lennon (2005) Re-visioning Trade and Development in the Pacific, Auckland: Oxfam New Zealand

DAC (2005) DAC Peer Review: New Zealand, Paris: Development Assistance Committee, OECD

Firth, S. (2005) The Impact of Globalization on the Pacific Islands, briefing paper for the 2nd South-East Asia and the Pacific Subregional Tripartite Forum on Decent Work, 5-8 April 2005, Melbourne

Focus on the Global South (2003) Anti Poverty or anti Poor: the Millennium Development Goals and the eradication of extreme poverty and hunger, Bangkok: Focus on the Global South

Gay, D. and R.M. Joy (n.d.) Vanuatu, UNESCAP, available at www.unescap.org/tid/ publication/t\&ipub2278_van.pdf, accessed 13 September 2005
Gibbs, K. (2007) 'Top lawyer embattled in Fiji coup', http://www.lawyersweekly.com.au/ articles/Top-lawyer-embattled-in-Fiji-coup_ z69226.htm

Greenhill, R. and P. Watt (2005) Real Aid: an agenda for making aid work, UK: Action Aid

Hardstaff, P. (2005) 'WDM media briefing on the UN Millennium Project report, edited by Jeffrey Sachs', World Development Movement, available at http://www.wdm. org.uk/news/sachsbrief.doc, accessed 13 October

Human Rights Watch (2005) 'Making Their Own Rules: police beatings, rape, and torture of children in Papua New Guinea', Human Rights Watch Report, 17 (8) (C), available at http://hrw.org/reports/2005/ png0905/, accessed 10 October 2005

Kahn, J. (2000) ‘The Mahogany King’s brief reign: business interests lurked behind Fiji's haphazard coup', New York Times, 14 September

Lennon, S. (2005) Make Extortion History: the case for development-friendly WTO accession for the world's poorest countries, Oxfam briefing paper, October

Maclellan, N. and P. Mares (2005) 'Labour mobility in the Pacific: creating seasonal work programs in Australia', paper 
presented at the Globalisation, Governance and the Pacific Islands conference, State,

Society and Governance in Melanesia Project, 25-27 October

Naidu, V. (2002) The Millennium Development Goals and the South Pacific, Suva: University of the South Pacific, available at http://www.devnet.org.nz/conf2002/ papers/ Naidu_Vijay.pdf, acccessed 20 September 2004

Naidu, V. and T. Wood (2008) A Slice of Paradise? The Millennium Development Goals in the Pacific: progress, pitfalls and potential solutions, Oceania Development Network working paper, Apia: Global Development Network

Narsey, W. (2004), PICTA, PACER AND EPAs: where are we going? Tales of fags, booze and rugby, University of the South Pacific working paper 2004/6

Oxfam (2005) The Fijian Sugar Industry: investing in sustainable technology, Oxfam briefing paper, September

Putnam, R., R. Leonardi and R. Nanetti (1994) Making Democracy Work: civic traditions in modern Italy, New Jersey: Princeton University Press

Rodrik, D. (2004) 'Rethinking growth policies in the developing world', Luca d'Agliano lecture in development economics delivered on 8 October 2004, available at http://ksghome.harvard.edu/ drodrik/ Luca_d_Agliano_Lecture_Oct_2004.pdf, accessed 20 September 2004

Scollay, R. (2001) Regional Trade Agreements and Developing Countries: the case of the Pacific Islands' proposed Free Trade Agreement, UNCTAD Policy Issues in International Trade and Commodities study series 10, document number UNCTAD/ ITCD/TAB/11, available at http://www. unctad .org /en/docs/itcdtab11_en.pdf, accessed 20 September 2005

Secretariat of the Pacific Community (2004) Pacific Islands Regional Millennium Development Goals Report 2004, Noumea: Secretariat of the Pacific Community

Solomon Islands Government (2005) National HIV Policy and Multisectoral Strategic Plan 2005-2010 Solomon Islands, Honiara: Solomon Islands Government, Solomon Islands National AIDS Council and nongovernmental organisations

Stiglitz, J. (2002) Globalization and Its

Discontents, London: Allen Lane

Storey, D. (2006) 'End of line? Globalisation and Fiji's garment industry', in S. Firth (ed.), Globalisation and Governance in the Pacific Islands, Canberra: ANU Press Tate, B. (2005) 'The NGO environment in Samoa: a case study of the socio-political environment's impact on local NGOs', thesis submitted as part of the Masters of Development Studies programme at Victoria University of Wellington

UN Millennium Project (2005) Investing in Development: a practical plan to achieving the Millennium Development Goals, Earthscan

UNAIDS (2004) Oceania: HIV and AIDS statistics and feature, available at: http:// www.unaids.org/wad2004/EPlupdate2004 _html_en/Epi04_10_en.htm, accessed 13 September 2005

Vandemoortele, J. (2002) Are the MDGs Feasible, available at http://www.undp. org/mdg/Are\%20the\%20MDGs\%20 feasible.doc, accessed 21 September 2005

Wood, T. 2004, 'Participatory democracy in Porto Alegre and Belo Horizonte', thesis submitted as part of the Masters of Development Studies programme at Victoria University of Wellington

\section{Climate Change and Security}

Planning for the Future

Edited by

Jonathan Boston

Philip Nel

Marjolein Righarts

Institute of Policy Studies

\section{Climate Change and Security: Planning for the Future}

Edited by Jonathan Boston, Philip Nel and Marjolein Righarts

Human-induced climate change

over the coming century is likely to

threaten not only physical ecosystems,

but also the security of individuals, societies, and states. By precipitating natural disasters, and by affecting the livelihood of communities, climate change may exacerbate existing social

An Institute of Policy Studies publication edited by Jonathan Boston,

Philip Nel and Marjolein Righarts

Publication May 2009 • Format - A5 paperback, pp 116

ISBN 978-1-877347-30-6 Price \$25.00 (including P\&P within New Zealand)

Place your order by email, phone, fax or mail to:

Institute of Policy Studies, Victoria University of Wellington

Email: ips@vuw.ac.nz Telephone +64 4463 5307, Fax + 6444637413

PO Box 600, Wellington, New Zealand

An invoice will be issued with your order tensions, create incentives for illegal actions, place unbearable strains on the capacities of states, and lead to resource disputes and struggles between and within states. This edited volume is the result of a symposium in Wellington in November 2008 that was convened to consider the factual bases for these claims, and to explore how New Zealand can and should respond. Rich in comparative material, the volume sounds a note of warning against both complacency and excessive scaremongering. 